\title{
Quantitative extraction of living Plathelminthes from marine sands
}

\author{
Uwe Noldt and Christian Wehrenberg
}

\begin{abstract}
II. Zoologisches Institut und Zoologisches Museum - Zoomorphologie und Okologie, Georg-August-Universität Göttingen, D-3400 Göttingen, Federal Republic of Germany
\end{abstract}

\begin{abstract}
Quantitative extraction of soft-bodied meiofauna from marine sands has been an unsolved problem. We describe and test the SMB-method (seawater, magnesium chloride, beaker), which combines several previously used methods. It yields high extraction efficiency for living Plathelminthes, when compared to both grain-method (equivalent to a thorough grain-by-grain inspection of the sample) and flask-method (based on anaesthetization with $\mathrm{MgCl}_{2}$-solution). Tested first on eulittoral sand, the latter 2 methods revealed significant personal bias for the 2 investigators, which for the SMB-method was avoided by adjusting the procedure of the technique in every detail. The sublittoral sets of samples subsequently studied proved the effectiveness of the SMB-method, which when tested against the grain-method did not differ significantly from it, either in overall examination or for single taxa of Plathelminthes. The SMB-method is recommended as a time-saving method with high extraction efficiency for living Plathelminthes from marine sands; it includes the following essential points: (1) 4 initial seawater-washes to avoid damage to delicate specimens; (2) application of hypertonic $\mathrm{MgCl}_{2}$-solution; (3) at least 1 final ethanol-wash; (4) use of a beaker of $1000 \mathrm{~cm}^{3}$; (5) 1 or 2 gauzes with minimum mesh size $40 \mu \mathrm{m}$; (6) sample volume must not exceed $50 \mathrm{~cm}^{3}$ in a ratio of $1: 5$ with the supernatant fluid; (7) multiple searches of Petri-dish contents. The 4 initial seawater-washes yielded $61 \%$ of the extracted Plathelminthes. Addition of the $\mathrm{MgCl}_{2}$-wash and 2 brief seawater-washes separated $97.3 \%$ of all individuals from the sediment. The final ethanol-washes were required only for Proseriata. Caution, however, must be advised as to species-specific extraction behavior in different sediments.
\end{abstract}

\section{INTRODUCTION}

Various attempts have been made to extract quantitatively meiofauna from marine sediments (Hulings and Gray, 1971; Uhlig et al., 1973), however, no one method is equally efficient for all types of sediment and all taxa of this small-sized fauna. Recently, Martens (1984) applied 3 methods to the interstitial Plathelminthes* and found none to be satisfactory. His 'Barnett-method' yielded the most individuals, but identification to species was severely impeded. The 'Uhlig-method' was good in the latter but not acceptable for quantitative studies.

Here we propose an extraction procedure which (1) yields living material required for identification; (2) is quantitative for Plathelminthes found in marine sand.

\footnotetext{
- We use the term 'Plathelminthes' instead of 'Turbellaria', and refer to this taxon as outlined by Ehlers (1984, in press) for reasons of phylogeny and priority of name
}

Our SMB-method (seawater, magnesium chloride in a beaker), which is essentially a new combination of the previous attempts cited above (see also Gray and Rieger, 1971; Elmgren, 1973), compares well with 2 others, a flask-method using seawater and magnesium chloride, and the very tedious method of looking directly through all the sand grains (grain-method).

\section{MATERIAL AND METHODS}

\section{Sampling}

Eulittoral samples were collected on May 17, 1983 at the 'Hausstrand' in front of the 'Alte Litoralstation' (List on Sylt, North Sea). The sample area was chosen at $1 \mathrm{~m}$ of the lower beach slope, where most major taxa of free-living Plathelminthes are abundant (Ehlers, 1973; Sopott, 1973; Hoxhold, 1974; Faubel, 1976). Median values of grain size have been measured by Schmidt 
(1968) and Hartwig (1973) as 447 and $482 \mu \mathrm{m}$, respectively. A rectangular area of water saturated sediment $\left(15 \times 60 \mathrm{~cm}^{2}\right)$ parallel to the waterline was divided in $3 \times 12$ squares of $25 \mathrm{~cm}^{2}$ each. We marked the midpoints of these squares and inserted 12 plastic corers (2.5 $\mathrm{cm}$ diameter, $5 \mathrm{~cm}^{2}$ surface area) 3 times successively to a depth of $5 \mathrm{~cm}$. We had chosen the general sample volume to be $25 \mathrm{~cm}^{3}$ to accommodate the quantity of samples required and the time calculated for the investigations of the cores with the grain-method.

On June 6, 1983 a second set of samples was taken in sublittoral sediments northwest of 'Ellenbogen' (12 m depth, close to buoy 'Lister Landtief No. 9'; $8^{\circ} 23^{\prime} 10^{\prime \prime}$ / $55^{\circ} 03^{\prime} 43^{\prime \prime}$ ). A Reineck Box Corer (total weight $150 \mathrm{~kg}$; box measures $\left.14.3 \times 14.3 \times 29.5 \mathrm{~cm}^{3}\right)$, modified with a rubber sealing (Farris and Crezée, 1976), was used. Once the apparatus was retrieved, the box was removed from the frame and immediately carried to the laboratory aboard.

The sediment surface was divided in 16 squares. Eight plastic corers (surface area $5 \mathrm{~cm}^{2}$ ) were driven into the sediment corresponding regularly to the 8 cells in one half of the box. As soon as the first row of corers had been pulled out (depth $15 \mathrm{~cm}$ ), another 8 corers were inserted in the remaining squares. This technique was essential, in order to prevent perturbation of the sediment. Furthermore, we added seawater every time a corer was pulled out, in order to restore the supernatant to its initial height. By doing this we tried to minimize a possible downward flow of water in the inserted corers. Both sets of samples were transferred to the laboratory within $1 \mathrm{~h}$ and stored at $12{ }^{\circ} \mathrm{C}$.

Eulittoral samples were subsequently apportioned to the authors in such a way that both investigators used both the flask- and grain-methods on alternate pairs of samples. The remaining samples, studied by employing the SMB-method, were similarly divided.

A chessboard-like dispersion of samples with respect to methods used and persons investigating was also chosen for the sublittoral samples (horizon c; 10 to $15 \mathrm{~cm}$ depth).

\section{Extraction}

(1) Flask-method. A $25 \mathrm{~cm}^{3}$ sample was washed into a plastic Erlenmeyer-flask $\left(250 \mathrm{~cm}^{3}\right.$, diameter of opening $4.4 \mathrm{~cm}$ ) with a jet of seawater. The flask was completely filled with seawater, closed with the palm of one hand, and rapidly rotated and inverted several times. The sediment was allowed to settle briefly. The supernatant was quickly poured into a funnel (Fig. 1c), equipped with a removable gauze holder at the outlet. This device consisted of 2 plastic tubes, which fitted tightly into one another, straining a nylon sieve (mesh size $40 \mu \mathrm{m})$. As soon as the water had run off, the gauze holder was loosened from the funnel and inverted closely above a Petri dish. Seawater was squirted through the sieve washing the residues into the Petri dish. The total of washes successively performed were: $2 \times$ seawater, $1 \times \mathrm{MgCl}_{2}\left(80 \mathrm{~g} \mathrm{MgCl}_{2} \cdot 6 \mathrm{H}_{2} \mathrm{O}\right.$ $1000 \mathrm{~cm}^{-3}$ freshwater $\hat{=} 37.5 \%$; $\left.15 \mathrm{~min}\right)$, and $4 \times$ seawater.

(2) Grain-method. This technique has been used by Reise and Ax (1979) for rather small sample volumes $\left(1 \mathrm{~cm}^{3}\right)$. Our approach - a grain-by-grain inspection of $25 \mathrm{~cm}^{3}$ samples - proved to be time-consuming ( 8 to $12 \mathrm{~h} \mathrm{sample}^{-1}$ ).

A single sample was divided in 4 portions. These were washed one by one into a beaker (plastic, $1000 \mathrm{~cm}^{3}$ ). Seawater was added to a total of about $150 \mathrm{~cm}^{3}$. The beaker was moderately shaken and rotated. Small portions of both - sediment and supernatant - were decantated into Petri dishes. Seawater was constantly added until no further grains were visible in the beaker. Thus a total of 100 Petri dishes was required for a single sample.

(3) SMB-method (seawater, magnesium chloride in a beaker; methodology and equipment in Fig. 1). A

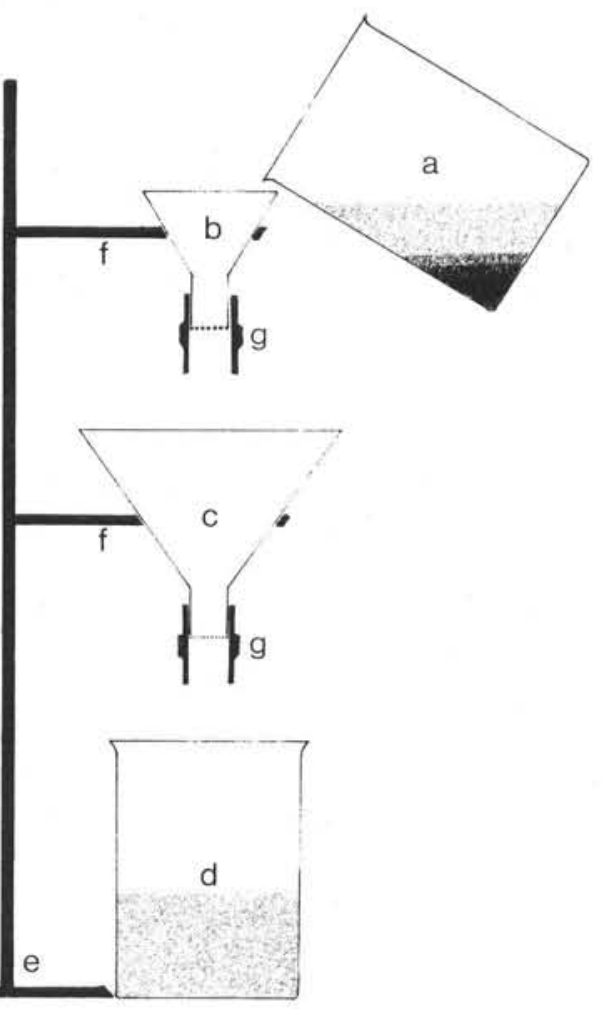

Fig. 1. SMB-method. Equipment and methodology. (a) Beaker filled with sample $\left(25 \mathrm{~cm}^{3}\right)$ and fluid $\left(125 \mathrm{~cm}^{3}\right)$; (b) small funnel with gauze holder (nylon sieve, mesh size $80 \mu \mathrm{m}$ ); (c) large funnel with gauze holder (mesh size $40 \mu \mathrm{m}$ ); (d) beaker for collection of waste water; (e) stand; (f) funnel holder; (g) gauze holder 
plastic beaker $\left(1000 \mathrm{~m}^{3}\right)$ was used as a container for the $25 \mathrm{~cm}^{3}$ sample. About 5 times the amount of fluid (seawater, $\mathrm{MgCl}_{2}$ or ethanol, respectively) was added before shaking and rotating the beaker. Brief resettling of the bulk of sediment was allowed before the supernatant was quickly poured into a cascade of 2 funnels with gauze holders (Fig. 1). For the upper holder (b) a gauze with $80 \mu \mathrm{m}$ mesh size was chosen, the lower one (c) contained a sieve of $40 \mu \mathrm{m}$ mesh size. Whenever a sieve became clogged causing the water flow to stop, we tapped gently on the rim of the funnel using the palm of one hand.

In total 10 washes were applied successively; $4 \times$ seawater, $1 \times \mathrm{MgCl}_{2}(37.5 \%, 15 \mathrm{~min}), 2 \times$ seawater (with animals still anaesthetized), and $3 \times$ ethanol ( $1 \times 5 \%$ ethanol, short application; $1 \times 5 \%$ ethanol, 10 min.; $1 \times 10 \%$ ethanol, $10 \mathrm{~min}$.). The use of 2 gauzes for each wash doubled the number of Petri dishes necessary.

\section{Sorting and examination}

Petri dishes were examined under a stereomicroscope. All Plathelminthes were picked out with small pipettes, squeezed, and identified under the compound microscope.

Investigations of eulittoral samples were limited to 2 samples per day and person (flask- and grain-method). Including the studies with the SMB-method the time required was $10 \mathrm{~d}$. Sublittoral samples took $10 \mathrm{~d}$ as well, since only half of the samples were studied by both investigators.

\section{Statistical analyses}

The Kolmogorov-Smirnov test for foodness of fit (in Sachs, 1984) was performed for all series of samples. One-way analysis of variance (ANOVA) was applied, in order to reveal significant differences between methods on the level of total abundance and taxonomic order. The t-test was used to detect personal bias of investigators and to demonstrate differences on overall abundance and taxonomic orders. All tests were also carried out with the nonparametric U-test (Wilcoxon et al., in Sachs, 1984).

\section{RESULTS}

\section{Eulittoral samples}

A total of 1710 Plathelminthes was counted in the 36 eulittoral samples (Table 1). Nineteen species belonging to 6 orders were identified (Table $3 \mathrm{~A}$ ). Within the

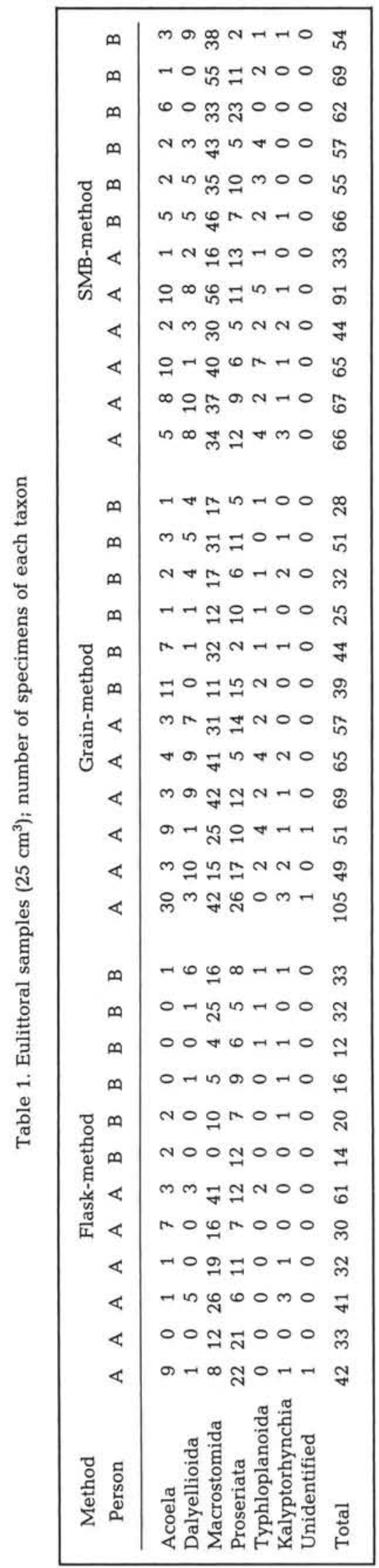


Acoela only Simplicomorpha giganto-rhabditis was identified, but other species - mainly juveniles - were present. Macrostomida (nearly all Microstomum papilIosum and $M$. jenseni) made up $56.2 \%$ of the total of Plathelminthes. Within the Kalyptorhynchia (1.9\% of the total) 6 species were found. Pogaina kinnei was dominant within the Dalyellioida $(71.8 \%)$, and Nematoplana coelogynoporoides within the Proseriata $(88.7 \%)$.

As shown in Table 4, the comparison (one-way analysis of variance) of the 3 techniques applied to the eulittoral samples resulted in significant differences between methods ( $F$ ratio 9.87; df $[2,33] ; \mathrm{p} \leq 0.001$ ). Samples examined by Persons A and B together yielded mean densities $\overline{\mathrm{x}}=30.5$ (flask-method), $\overline{\mathrm{x}}=$ 51.3 (grain-method), and $\bar{x}=60.8$ (SMB-method). No significant differences between methods were found for Person A (F ratio 3.59; df $[2,15]$; $p$ : ns), whereas samples studied by Person B showed high significance (F ratio 31.93 ; df $[2,15] ; \mathrm{p} \leq 0.001$ ).

Extraction with the flask-method was least efficient. The grain-method and SMB-method did not differ significantly in overall extraction efficiency. Personal bias, however, was obvious for both methods (see contrasts in Table 4).

One-way ANOVA was applied to the level of taxonomic order as well. Significant differences between the methods were obtained for Macrostomida, Typhloplanoida, and Dalyellioida only (F ratios 12.70, 8.20, and 3.86, respectively). The flask-method showed lowest extraction efficiencies for these orders. Only the Macrostomida were extracted significantly better with the SMB-method than with the grain-method.

The application of the nonparametric U-test in place of the t-tests corroborated these results.

\section{Sublittoral samples}

The 31 sublittoral cores yielded a total of 616 Plathelminthes (Table 2). Eleven species were identified (Table $3 \mathrm{~B}$ ); Acoela were classified on the orderlevel only. $56.3 \%$ of all Plathelminthes belonged to the Proseriata; Otoplanidae and Coelogynoporidae exceeded the Nematoplanidae $(49.3 \%, 45.0 \%$, and $5.5 \%$, respectively). All but 2 specimens of the Typhloplanoida were Petaliella spiracauda.

Fifteen samples of the sublittoral horizon c (10-15 $\mathrm{cm}$ depth) were investigated with the grain- and the SMB-method (ratio 8:7) by Persons A and B (Table 2). No significant differences between the 2 techniques were found (Table 5). Mean densities were $\bar{x}=24.1$ for the grain-method and $\bar{x}=23.0$ for the SMB-method. One-way ANOVA resulted in an $\mathrm{F}$ ratio $=0.01, \mathrm{df}$ $(1,13)$, and $p$ not significant. Significant differences

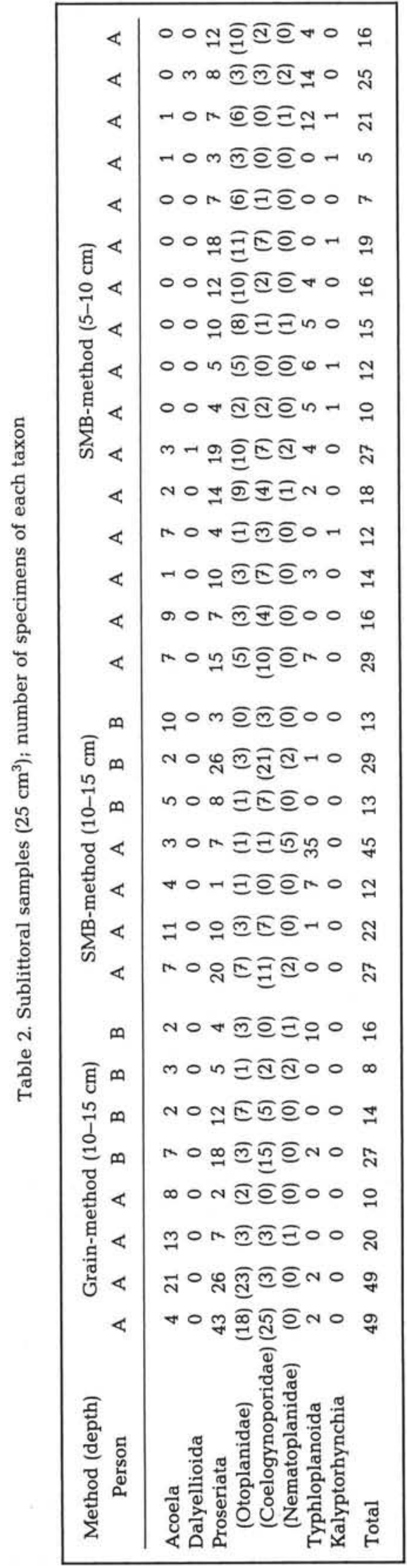


Table 3. Species identified in eulittoral (A) and sublittoral (B) samples

(A) Acoela

Simplicomorpha gigantorhabditis Dörjes, 1968

Dalyellioida

Pogaina kinnei Ax, 1970

Macrostomida

Microstomum papillosum Graff, 1882

Microstomum jenseni Riedel, 1932

Proseriata

Dicoelandropora atriopapillata Ax, 1956

Parotoplana papii Ax, 1956

Parotoplanella progermaria Ax, 1956

Praebursoplana steinböcki Ax, 1956

Nematoplana coelogynoporoides Meixner, 1938

Typhloplanoida

Litucivis serpens Ax et Heller, 1970

Brinkmanniella macrostomoides Luther, 1948

Promesostoma serpentistylum Ax, 1952

Promesostoma sp.

Kalyptorhynchia

Gyratrix hermaphroditus Ehrenberg, 1831

Marirhynchus longasaeta Schilke, 1970

Neopolycystis tridentata Karling, 1955

Paraschizorhynchoides glandulis Schilke, 1970

Thylacorhynchus caudatus Meixner, 1928

Diascorhynchides arenaria Schilke, 1970

(B) Dalyellioida

Breslauilla relicta Reisinger, 1929

Breslauilla aurora nom. nud.

Typhloplanoida

Petaliella spiracauda Ehlers, 1974

Subulagera rubra Martens et Schockaert, 1981

Proseriata

Parotoplana capitata Meixner, 1938

Parotoplana primitiva Ax, 1956

Kataplana mesopharynx Ax, 1956

Coelogynopora axi Sopott, 1972

Cirrifera boletiformae Sopott, 1972

Cirrifera aculeata (Ax, 1951)

Nematoplana coelogynoporoides Meixner, 1938

were not obtained for investigations by either person, nor between methods applied by each person (see contrasts and mean densities in Table 5).

All 16 samples of the sublittoral horizon b $(5$ to $10 \mathrm{~cm}$ depth) were investigated with the SMB-method by Person A alone, in order to supply additional data on extraction efficiencies of single washes.

\section{Extraction efficiencies of single washes of the SMB-method}

All specimens extracted with the SMB-method were grouped according to the 10 successive washes (Steps I to $\mathrm{X}$ in Fig. 2). In total, $61.0 \%$ of all Plathelminthes were extracted during the 4 washes with seawater prior to anaesthetization with $\mathrm{MgCl}_{2}$. The latter and the 2 subsequent seawater-washes (with animals still narcotized) yielded $36.3 \%$, whereas the final washes with ethanol amounted to only $2.7 \%$ of the total (Fig. $2 \mathrm{~A})$. The highest efficiency of extraction was observed in the $\mathrm{MgCl}_{2}$-wash (Step V).

At the level of taxonomic orders, 3 types of extraction efficiencies could be distinguished (Fig. 2 B): (a) Dalyellioida were extracted with seawater-washes alone $(94.8 \%$, highest efficiency at step I); (b) increasing amounts of Macrostomida and Acoela were found correlated with increasing number of washes; a total of $85.7 \%$ of Macrostomida and $59.5 \%$ of Acoela were extracted with the seawater-washes, most efficiently in Steps IV and V, respectively; (c) extraction efficiencies for Proseriata were low in seawater $(35.2 \%$ in 4 washes), but high when washes with narcosis were used $(59.0 \%)$. The final ethanol-washes yielded highest efficiencies for the Proseriata $(5.8 \%)$.

Separate graphs for eulittoral and sublittoral Typhloplanoida (Fig. 2 C) show an opposing trend of extraction efficiencies between seawater- and $\mathrm{MgCl}_{2}$ washes. A similar difference on the level of taxonomic order was found in the Acoela, although no distinct peak as in Step V for sublittoral Typhloplanoida occurred.

Separate plots for the sublittoral proseriate families Otoplanidae and Coelogynoporidae reveal different extraction efficiencies (Fig. 2 D). Extraction of the proseriate Nematoplana coelogynoporoides resembled that of the Coelogynoporidae.

\section{DISCUSSION}

A recent comparison of 3 different extraction methods for interstitial Plathelminthes (Martens, 1984) yielded highest overall extraction efficiency for the Barnett-method, applied to preserved material (initially Harpacticoida, Barnett, 1968). The technique was compared to the Uhlig- and $\mathrm{MgCl}_{2}$-methods (both for living material). Using the latter methods, extraction efficiencies of less than $50 \%$ were obtained. An exception to the generally high efficiency of the Barnettmethod was the taxon Acoela (and with reservations the taxa Retronectida and Dalyellioida as well), which were separated more efficiently with the Uhligmethod. For quantitative studies, Martens (l.c.) therefore proposed applying a combination of methods, the Uhlig- and the Barnett-method successively. For qualitative studies the use of either the Uhlig- or the $\mathrm{MgCl}_{2}$-technique was recommended. For all practical purposes, this procedure is unsatisfactory.

In contrast to Martens (1984) we obtained a very efficient extraction method for living Plathelminthes from marine sands. This SMB-method combines initial seawater-washes with a subsequent $\mathrm{MgCl}_{2}$-wash and 
Table 4. One-way analysis of variance (ANOVA) of methods used for the eulittoral samples. ns not significant; * $(\mathrm{p} \leq 0.05)$; ** $(\mathrm{p} \leqslant 0.01) ;$ * $(\mathrm{p} \leqslant 0.001)$

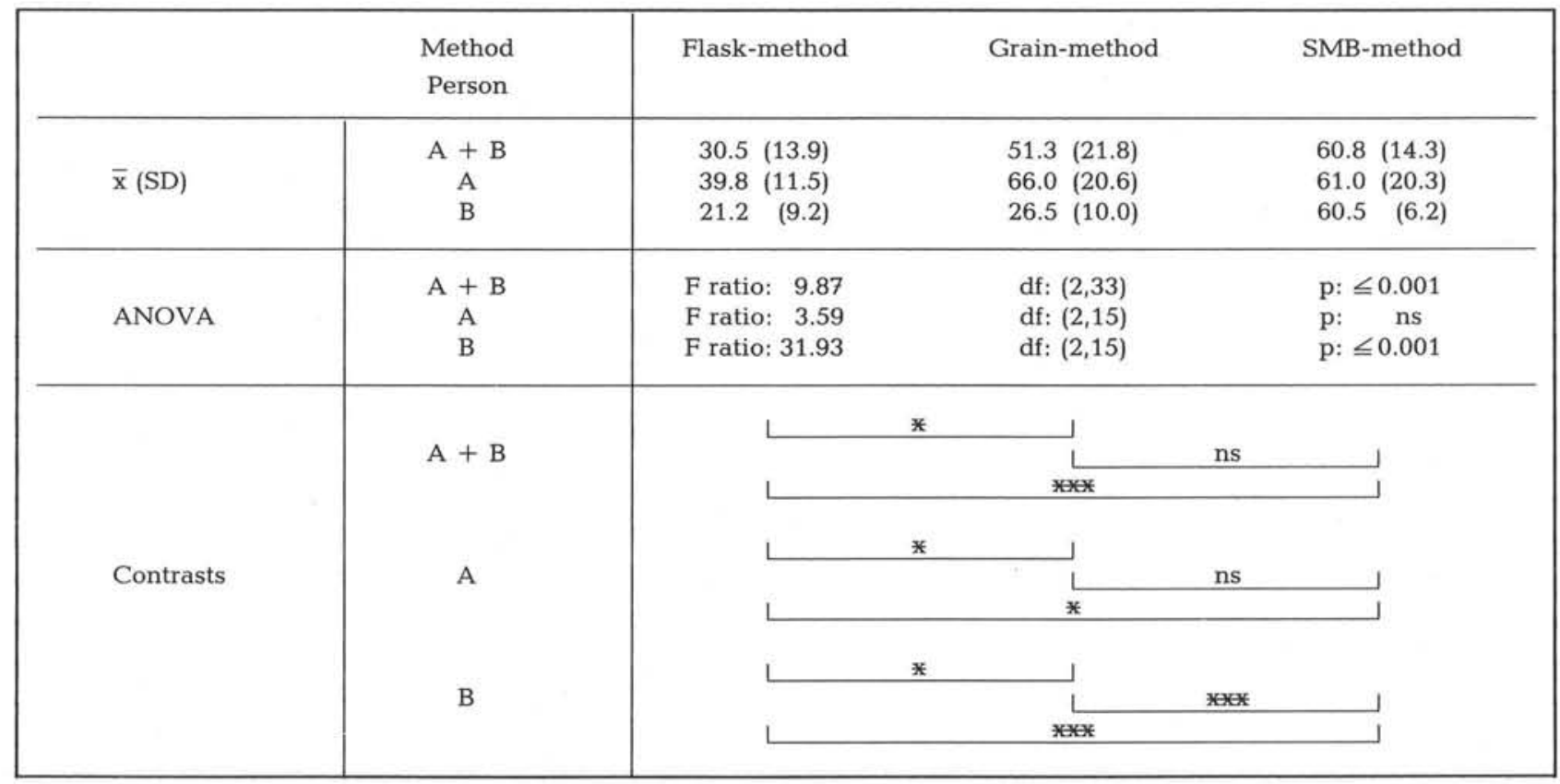

Table 5. One-way analysis of variance (ANOVA) of methods used for the sublittoral samples

\begin{tabular}{|c|c|c|c|}
\hline & $\begin{array}{l}\text { Method } \\
\text { Person }\end{array}$ & Grain-method & SMB-method \\
\hline $\bar{x}(S D)$ & $\begin{array}{c}A+B \\
A \\
B\end{array}$ & $\begin{array}{lr}24.1 & (16.4) \\
32.0 & (20.0) \\
16.3 & (7.9)\end{array}$ & $\begin{array}{lr}23.0 & (12.0) \\
26.5 & (13.8) \\
18.3 & (9.2)\end{array}$ \\
\hline ANOVA & $A+B$ & F ratio: 0.01 & $\mathrm{p}: \mathrm{ns}$ \\
\hline Contrasts & $\begin{array}{l}\text { A } \\
\text { B }\end{array}$ & 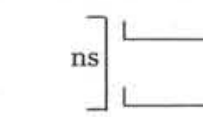 & is \\
\hline
\end{tabular}

final ethanol-washes. The extraction efficiency of the SMB-method does not significantly differ from the grain-method, which is based on thorough grain-bygrain search.

The flask-method was the least efficient. This technique was first described by Boaden (1963), who applied 3 initial seawater-washes before anaesthetization with $\mathrm{MgCl}_{2}$-solution (6\%). In later studies, no further mention of seawater-washes was made and apparently they were omitted (Boaden, 1968, 1976, 1980; Boaden and Platt, 1971; Sterrer, 1968; Gray and Rieger, 1971; Crezée, 1976).

The grain-method is efficient but is too time-consuming when applied to samples larger than 1 to $5 \mathrm{~cm}^{3}$. By detailed inspection of the large number of Petri dishes and 2 searches per dish information about the 'extraction behavior' of the different taxa of Plathelminthes was obtained. Acoela, Dalyellioida, Macrostomida, and the very limited number of Typhloplanoida and Kalyptorhynchia were swirled into the first sets of Petri dishes, whereas Proseriata 'stuck to the last grains' in the final Petri dishes.

The SMB-method combined several slightly modified elements of techniques mentioned above: (1) 4 initial seawater-washes, (2) narcosis with hypertonic $\mathrm{MgCl}_{2}$, (3) 2 seawater-washes animals still anaesthetized, (4) final washes with different ethanol concentrations, and (5) 2 gauzes with mesh sizes of 80 and $40 \mu \mathrm{m}$ (Elmgren, 1973; Thiel in Uhlig et al., 1973).

Fractionating with 2 gauzes and a total of 10 different washes made the examination of Petri dishes much easier since fine particles were scattered, but also more time-consuming. This extra time, however, was worthwhile since most of the Plathelminthes were extracted with the 4 initial seawater-washes $(61.0 \%)$ and nearly all specimens were recovered by adding the subsequent $\mathrm{MgCl}_{2}$-treatment $(97.3 \%)$.

Gray and Rieger (1971) examined the extraction by an initial treatment with $\mathrm{MgCl}_{2}$ (including 3 subsequent seawater-washes) followed by application of $10 \%$ ethanol ( +3 seawater-washes). The authors assumed an extraction efficiency of almost $100 \%$. Plathelminthes were extracted with rates of 67 and $33 \%$, respectively by the 2 treatments. In contrast to these data, an almost negligible percentage was obtained for the ethanol-washes in the SMB-method. 
Fig. 2. SMB-method. Percentages of extraction efficiencies of single washes (I to IV: seawater; V: $\mathrm{MgCl}_{2}, 37.5 \%, 15$ min; VI + VII: seawater with anaesthetized animals; VIII: ethanol, 5\%, short application; IX ethanol, $5 \%, 10 \mathrm{~min}$; $\mathrm{X}$ : ethanol, $10 \%, 10 \mathrm{~min})$. Percentages of total of individuals within the boundaries (seawater, $\mathrm{MgCl}_{2}$, ethanol) indicated above. (A) Total of Plathelminthes extracted employing SMB-method. (B) Total of individuals of the orders Acoela (Ac), Dalyellioida (Dal), Macrostomida (Mac), and Proseriata (Pros). (C) Total of sublittoral and eulittoral Typhloplanoida. (D) Total of sublittoral Otoplanidae (Oto) and Coelogynoporidae (Coel)

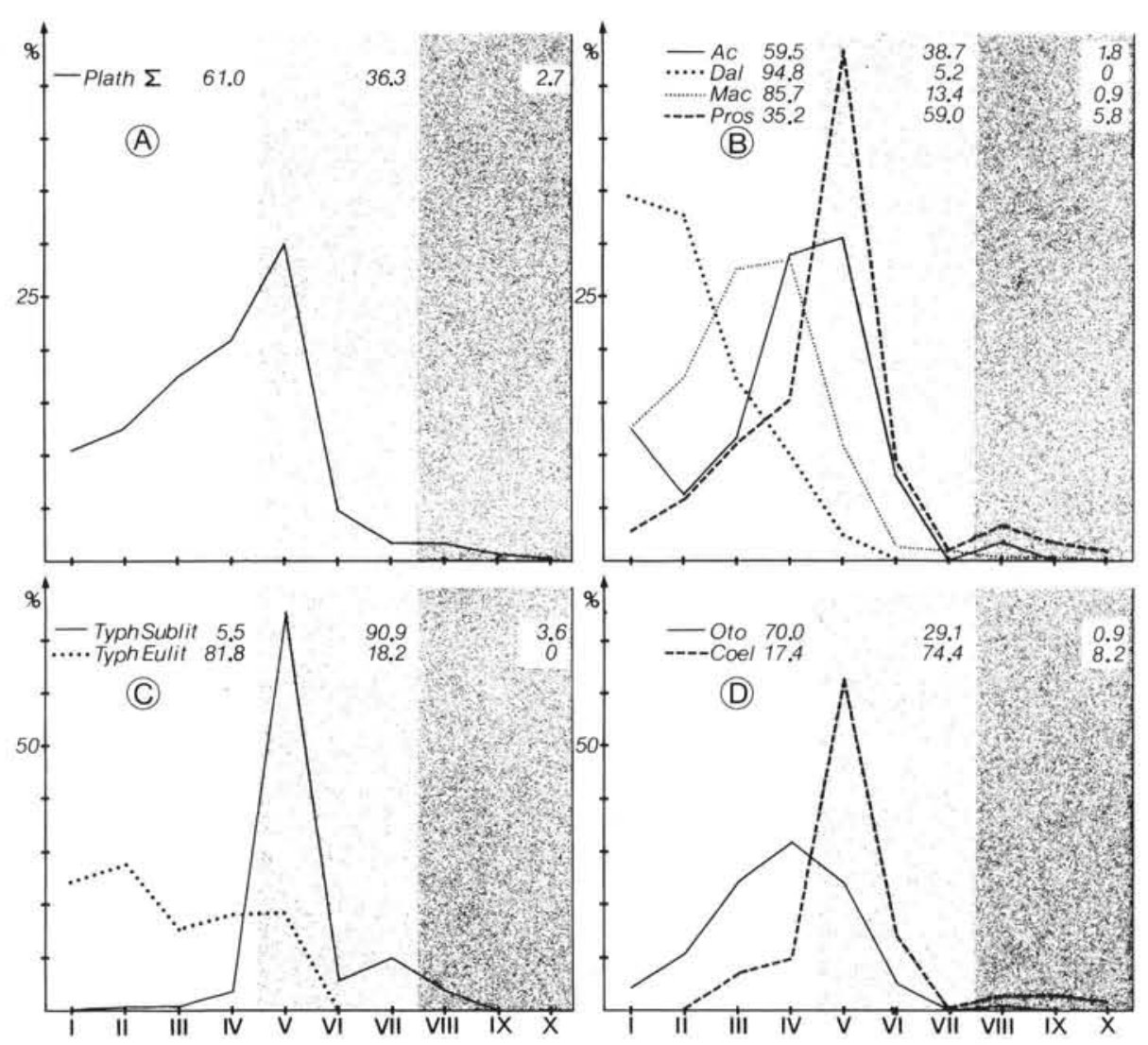

Lowest extraction efficiencies ( $=$ mean densities) were obtained for the flask-method in examinations by either author and consequently in the overall study. Mean densities of overall examination were significantly higher by the grain-method. In both techniques, however, a significant personal bias was found. We therefore adjusted every detail of procedure within the SMB-method, with the result that no significant differences between investigators were detected. The SMBmethod yielded highest extraction efficiency for the overall investigation, whereas the highest mean density was found by Person A using the grainmethod. These results emphasize personal sorting efficiency as a major source of error, especially in dealing with new sample qualities and quantities. Therefore preventive double-searches by different persons (Coull et al., 1977) are advised, even for one major taxon at the beginning of each quantitative study.

The results of extraction efficiencies for the single taxa of Plathelminthes are very similar to the overall differences between the 3 methods tested. The flaskmethod was least efficient in the separation of Dalyellioida, Macrostomida, Typhloplanoida, and Acoela, whereas the grain- and SMB-methods differed significantly only in respect to the taxon Macrostomida. This exception to the better overall extraction with the
SMB-method is caused by the low efficiency for Person $B$ investigating with the grain-method. No results could be obtained for the least abundant taxon Kalyptorhynchia. For the Proseriata (mainly Nematoplana coelogynoporoides) no significant differences between the 3 methods were detected.

The subsequent investigations of the sublittoral samples were performed, in order to test the grain- and SMB-methods on a different sample type. Again, no significant differences were found between methods, investigators, and when applied to single taxa.

Additional data were obtained from the sublittoral samples about the efficiencies of single washes within the SMB-method. In general, Dalyellioida, Macrostomida, and Acoela were recovered in rates of $60 \%$ or more with the seawater-washes alone. Proseriata and Typhloplanoida on the other hand, were extracted substantially ( $60 \%$ or more) only when anaesthetized. Further restrictions emerged when the extraction behaviour' was examined with respect to (1) the taxonomic level of families or (2) eulittoral and sublittoral species composition.

(1) For the Proseriata - the only taxon for which final ethanol-washes must be recommended - division into the families Otoplanidae, Coelogynoporidae, and Nematoplanidae demonstrates contrasting extraction 
efficiencies for these taxa. The long individuals of the latter 2 families were found with numerous adhered grains mainly in the $\mathrm{MgCl}_{2}$-washes and in the final ethanol-washes. The insensitivity of these robust specimens to the entire extraction process is obvious. Furthermore, the result exemplifies that immediate decantation of the supernatant after swirling, inverting, or shaking of the sample is essential, in order to avoid instant settling of such 'heavy' specimens.

(2) For the Typhloplanoida, contrasting extraction efficiencies within the boundaries of seawater- and $\mathrm{MgCl}_{2}$-washes with respect to eulittoral and sublittoral species were obtained. Although not determined on species-level, an equivalent result was found for the Acoela of both habitats. Consequently, the biology of the single species must be considered when methods are compared.

We confirm the assumption made by Martens (1984), that inefficient separation of Acoela is caused by application of his $\mathrm{MgCl}_{2}$-method. We even conclude from the data of our flask-method that decreased efficiency is to be expected for Dalyellioida and Macrostomida (i.e. Pogaina kinnei and paratomizing Microstomum species) as well, when vigorous mixing is applied to the sample. In addition we assume these delicate specimens to be damaged by sudden exposure to $\mathrm{MgCl}_{2}$-solution.

When rotating and shaking a sample in a flask we observed that the bulk of sediment remained close to the bottom of the container as a result of the narrowing circumference. Additional inverting of the closed flask (emphasized by Crezée, 1976) required a longer time for the lighter particles to resettle. If the supernatant fluid was decantated immediately, tedious sorting of the Petri dishes resulted. Moderate swirling of sediment in a beaker on the other hand, did not secure instant separation or thorough mixing. The repeated procedure of careful mixing, however, along with subsequent narcotization, assured utmost extraction of undamaged specimens.

For a beaker of $1000 \mathrm{~m}^{3}$, the sample volume and the quantity of supernatant fluid were observed to be best suited in a ratio of $1: 5$ with sample size not exceeding $50 \mathrm{~cm}^{3}$. Any increment beyond this ratio made mixing of the sample incomplete.

In contrast to Martens (1984), we found that Acoela and other small Plathelminthes are retained by a combination of 2 sieves with mesh sizes of 80 and $40 \mu \mathrm{m}$. Repeated examination of the water and gauzes used yielded neither washed out nor retained specimens (see Elmgren, 1973 for preserved material).

The highest extraction efficiency for living Plathelminthes from marine sands was obtained with the SMB-method when compared to thorough grain-bygrain search. We are aware that limiting factors for complete effectiveness of the method still exist: these include (1) personal sorting efficiency; (2) application of a large number of mechanical treatments (i.e. washes) which 'could work upon animals like a mill' (Uhlig, 1968); (3) the fact that its applicability to fine sands has not yet been tested to a comparable extent.

We recommend the SMB-method as a time-saving technique for live-extraction of interstitial Plathelminthes, under the following prerequisites:

(1) Four initial seawater-washes are followed by $1 \mathrm{MgCl}_{2}$-wash $\left(80 \mathrm{~g} \mathrm{MgCl}_{2} \cdot \mathrm{H}_{2} \mathrm{O} 1000 \mathrm{~cm}^{-3}\right.$ freshwater, $15 \mathrm{~min}$ ), 2 seawater-washes (or short $\mathrm{MgCl}_{2}$ washes again), and at least 1 ethanol-wash (10\%, $10 \mathrm{~min}$.);

(2) use of 2 gauzes (smallest mesh size $40 \mu \mathrm{m}$ );

(3) sample size limited to $50 \mathrm{~cm}^{3}$ in a beaker of $1000 \mathrm{~cm}^{3}$;

(4) ratio of sample to supernatant fluid 1:5;

(5) multiple searches of Petri dishes.

Acknowledgements. We thank first of all Dr. Karsten Reise for continuous help in every way. We are indebted to the staff of the 'Biologische Anstalt Helgoland, Litoralstation List' and the director Professor Otto Kinne for hospitality and for providing valuable cooperation. Dr. Peter Martens helped with the statistical analyses, and Peter Elvert und Nils Kruse of RV 'Mya' provided technical assistance.

This research was supported by a grant of the 'Deutsche Forschungsgemeinschaft' to Professor Peter Ax.

\section{LITERATURE CITED}

Barnett, P. R. O. (1968). Distribution and ecology of Harpacticoid copepods of an intertidal mudflat. Int. Revue ges. Hydrobiol. 53: 177-209

Boaden, P. J. S. (1963). The interstitial fauna of some North Wales beaches. J. mar. biol. Ass. U. K. 43: 79-96

Boaden, P. J. S. (1968). Water movement - a dominant factor in the interstitial ecology. Sarsia 34: 125-136

Boaden, P. J. S. (1976). Soft meiofauna of sand from the Delta region of the Rhine, Meuse and Scheldt. Neth. J. Sea Res. 10: $461-471$

Boaden, P. J. S. (1980). Meiofaunal thiobios and 'the Arenicola negation': case not proven. Mar. Biol. 58: 25-29

Boaden, P. J. S., Platt, H. M. (1971). Daily migration pattern in an intertidal meiobenthic community. Thalassia jugosl. 7: $1-12$

Coull, B. C., Ellison, R. L., Fleeger, J. W., Higgins, R. P., Hope, W. D., Hummon, W. D., Rieger, R. M., Sterrer, W. E., Thiel, H. Tietjen, J. H. (1977). Quantitative estimates of the meiofauna from the deep sea off North Carolina, USA. Mar. Biol. 39: 233-240

Crezée, M. (1976). Solenofilomorphidae (Acoela), major component of a new turbellarian association in the sulfide system. Int. Revue ges. Hydrobiol. 61: 105-129

Ehlers, U. (1973). Zur Populationsstruktur interstitieller Typhloplanoida and Dalyellioida (Turbellaria, Neorhabdocoela). Mikrofauna Meeresboden 19: 1-105

Ehlers, U. (1984). Phylogenetic relationships within the Plathelminthes. In: Conway Morris, S., George, J., D., Gibson, R., Platt, H. M. (ed.) The origins and relationships 
of lower invertebrates. Systematics Association Special Volume No., University Press, Oxford, in press

Elmgren, R. (1973). Methods of sampling sublittoral soft bottom meiofauna. Oikos 15 (Suppl.): 112-120

Farris, R. A., Crezée, M. (1976). An improved Reineck Box for sampling coarse sand. Int. Revue ges. Hydrobiol. 61: 703-705

Faubel, A. (1976). Populationsdynamik und Lebenszyklen interstitieller Acoela und Macrostomida (Turbellaria). Mikrofauna Meeresboden 56: 1-107

Gray, J. S., Rieger, R. M. (1971). A quantitative study of the meiofauna of an exposed sandy beach, at Robin Hood's Bay, Yorkshire. J. mar. biol. Ass. U. K. 51: 1-19

Hartwig, E. (1973). Die Ciliaten des Gezeiten-Sandstrandes der Nordseeinsel Sylt. II. Okologie. Mikrofauna Meeresboden 21: 1-171

Hoxhold, S. (1974). Populationsstruktur und Abundanzdynamik interstitieller Kalyptorhynchier. Mikrofauna Meeresboden 41: 1-134

Hulings, N. C., Gray, J. S. (1971). A manual for the study of meiofauna. Smithson. Contr. Zool. 78: 1-83

Martens, P. M. (1984). Comparison of three different extraction methods for Turbellaria. Mar. Ecol. Prog. Ser. 14: 229-234
Reise, K., Ax, P. (1979). A meiofaunal 'Thiobios' limited to the anaerobic sulfide system of marine sand does not exist. Mar. Biol. 54: 225-237

Sachs, L. (1984). Angewandte Statistik. Anwendung statistischer Methoden. Springer, Berlin

Schmidt, P. (1968). Die quantitative Verteilung und Populationsdynamik des Mesopsammons am Gezeiten-Sandstrand der Nordseeinsel Sylt. I. Faktorengefüge und biologische Gliederung des Lebensraumes. Int. Revue ges. Hydrobiol. 53: 723-779

Sopott, B. (1973). Jahreszeitliche Verteilung und Lebenszyklen der Proseriata (Turbellaria) eines Sandstrandes der Nordseeinsel Sylt. Mikrofauna Meeresboden 15: 1-106

Sterrer, W. (1968). Beiträge zur Kenntnis der Gnathostomulida. I. Anatomie und Morphologie des Genus Pterognathia Sterrer. Ark. Zool. 22: 1-125

Uhlig, G. (1968). Quantitative methods in the study of interstitial fauna. Trans. Microsc. Soc. 87: 226-232

Uhlig, G., Thiel, H., Gray, J. S. (1973). The quatitative separation of meiofauna. A comparison of methods. Helgoländer wiss. Meeresunters. 25: 173-195 